\title{
Wound healing activity of the lipophilic extract of Tagetes erecta L.
}

\author{
0. 0. Maliuhina*, H. P. Smoilovska, I. F. Bielenichev, O. V. Mazulin, T. V. Khortetska
}

Zaporizhzhia State Medical University, Ukraine

Nowadays, one of the most important problems of clinical care is assisting the healing process in acute and chronic wounds of various origins. Current interest direction of drug therapy is the use of phytomedicines. African marigold is one of the most promising ones to obtain medicine for wound healing. According to literature data, extracts and individual compounds of marigold show antimicrobial, wound healing, antioxidant, anti-inflammatory and analgesic activity. Lipophilic extract of marigold is non-toxic and does not have local irritating and allergic effects.

The aim of our research was to study the wound healing activity of the lipophilic extract obtained from the inflorescences of African marigold tall forms of the variety "Hawaii" (Tagetes erecta plena L. var. "Hawaii").

Materials and methods. The lipophilic extract was obtained from inflorescences of Tagetes erecta plena L. by extraction with corn deodorized oil in a ratio of 1:6. The resulting lipophilic extract was standardized for the content of carotenoids and flavonoids. The wound healing effect of the extract was determined based on the example of a simulated burn healing according to the time of perifocal reaction disappearance, skin sloughing, formation of granulation, initiation of marginal epithelialization and the end of healing. The number of animals with completely epithelialized wounds was determined on days 25 and 30 of the experiment.

Results. The quantitative content of carotenoids (up to $80.51 \pm 1.15 \mathrm{mg} \%$ equivalent to $\beta$-carotene) and flavonoids (up to $0.7120 \pm 0.0060 \%$ equivalent to patuletin) was determined by the lipophilic extract of Tagetes erecta plena L. var. «Hawaii» standardization. The duration of experimental wounds healing when applying the extract and reference preparation was up to $30.7 \pm 1.4$ days and $28.0 \pm 1.8$ days, respectively, which was significantly less than in the control group (up to $47.7 \pm 4.0$ days). Full epithelization of wounds was observed on day 25 of the experiment in $60 \%$ of the animals receiving the extract, in $70 \%$ of the animals receiving the reference preparation and only in $10 \%$ of the animals which did not receive a treatment. On day 30 of the experiment, this indicator was 80,90 and $30 \%$, respectively. The results of the experiment reliably testify to the fact that in animals treated with the studied lipophilic extract, the healing time of burn wounds was significantly less than in the untreated control group animals and practically did not differ from the healing time in animals treated with sea buckthorn oil.

Conclusions. The lipophilic extract from inflorescences of Tageta erecta plena L. var. "Hawaii" has been studied for wound healing activity. The stages duration and the time of experimental wounds complete healing in animals receiving the studied extract and reference preparation were significantly reduced in comparison to the control group animals.

\section{Ранозагоювальна активність міпофільного екстракту чорнобривців прямостоячих}

\section{О. О. Малюгіна, Г. П. Смойловська, І. Ф. Бєленічев, О. В. Мазулін, Т. В. Хортецька}

Нині однією з найважливіших проблем клінічної допомоги є сприяння процесу загоєння гострих і хронічних ран різного походження. Актуальним напрямом лікарської терапії є використання фітопрепаратів. Найперспективнішим джерелом фітопрепаратів ранозагоювальної дії є чорнобривці прямостоячі (Tagetes erecta L.). Згідно з даними фрахової літератури, екстракти та індивідуальні сполуки чорнобривців прямостоячих проявляють протимікробну, ранозагоювальну, антиоксидантну, протизапальну і знеболювальну активність. Ліпофільний екстракт чорнобривців прямостоячих - нетоксичний, не виявляє місцевоподразнювальної та алергізуючої дії.

Мета роботи - вивчення ранозагоювальної активності ліпофрільного екстракту, який отримали з суцвіть чорнобривців прямостоячих високорослої форми сорту «Гаваї» (Tagetes erecta plena L. var. «Hawaii»).

Матеріали та методи. Ліпофільний екстракт одержували з суцвіть чорнобривців екстракцією олією кукурудзяною дезодорованою у співвідношенні 1 : 6. Отриманий ліпофільний екстракт стандартизували за вмістом каротиноїдів і фрлавоноїдів. Ранозагоювальну дію екстракту визначали на прикладі загоєння змодельованого опіку за часом усунення перифокальної реакції, відторгнення струпу, появи грануляції, початку крайової епітелізації та завершення загоєння. На 25 і 30 добу експерименту визначали кількість тварин, що мають повністю епітелізовані рани

Результати. При стандартизації ліпофільного екстракту чорнобривців прямостоячих сорту «Гаваї» встановили кількісний вміст каротиноїдів (до 80,51 \pm 1,15 мг\% у перерахунку на $\beta$-каротин) і фрлавоноїдів (до 0,7120 \pm 0,0060 \% у перерахунку на патулетін). Тривалість загоєння експериментальних ран при застосуванні досліджуваного екстракту та референс-препарату становила до $30,7 \pm 1,4$ доби і до $28,0 \pm 1,8$ доби відповідно, що істотно менше, ніж у контрольній групі (до 47,7 £ 4,0 доби). Повна епітелізація ран спостерігалася на 25 добу експерименту в 60 \% тварин, які отримували досліджуваний екстракт, 70 \% тварин, які отримували референс-препарат, і тільки в 10 \% тварин, які не отримували лікування. На 30 добу експерименту цей показник становив 80, 90 і 30 \% відповідно. Результати експерименту вірогідно показують, що у тварин, яких лікували досліджуваним ліпофрільним екстрактом, час загоєння опікових ран був істотно меншим, ніж у нелікованих тварин контрольної групи, і практично не відрізнявся від часу загоєння у тварин, яких лікували з використанням обліпихової олії.

Висновки. Вивчена ранозагоювальна активність ліпофільного екстракту, що отримали з суцвіть Tagetes erecta plena $\mathrm{L}$. var. «Hawaï». Встановили, що тривалість етапів і час повного загоєння експериментальної рани у тварин, які одержували досліджуваний екстракт і референс-препарат, істотно нижче, ніж у тварин контрольної групи, які не отримували лікування.
Key words: Tagetes erecta L., plant extracts, wound healing.

Zaporozhye medical journal 2019; 21 (2), 253-257 DOI: 10.14739/2310-1210 2019.2.161510

*E-mail: maluginaea@gmail.com
Киючові слова: Tagetes erecta L., рослинний екстракт, ранозагоювальна активність.

Запорізький медичний журнал. - 2019. T. 21, № 2(113). C. 253-257 
Ключевые слова: Tagetes erecta L., растительный экстракт, ранозаживляющая активность.

Запорожский медицинский журнах. - 2019. T. 21, № 2(113). C. 253-257

\title{
Ранозаживляющая активность мипофильного экстракта бархатцев прямостоячих
}

\author{
Е. А. Малюгина, Г. П. Смойловская, И. Ф. Беленичев, А. В. Мазулин, Т. В. Хортецкая
}

В настоящее время одной из наиболее важных проблем клинической помощи является содействие процессу заживления острых и хронических ран различного происхождения. Актуальным направлением лекарственной терапии является использование фитопрепаратов. Наиболее перспективным источником фитопрепаратов ранозаживляющего действия являются бархатцы прямостоячие (Tagetes erecta L.). Согласно данным литературы, экстракты и индивидуальные соединения бархатцев прямостоячих проявляют противомикробную, ранозаживляющую, антиоксидантную, противовоспалительную и обезболивающую активность. Липофильный экстракт бархатцев прямостоячих является нетоксичным, не проявляет местнораздражающее и аллергизирующее действия.

Цель работы - изучение ранозаживляющей активности липофиильного экстракта, полученного из соцветий бархатцев прямостоячих высокорослой формы сорта «Гавайи» (Tagetes erecta plena L. var. «Hawaii»).

Материалы и методы. Липофильный экстракт получали из соцветий бархатцев экстракцией маслом кукурузным дезодорированным в соотношении 1:6. Полученный липофильный экстракт стандартизировали по содержанию каротиноидов и флавоноидов. Ранозаживляющее действие экстракта определяли на примере заживления смоделированного ожога по времени устранения перифокальной реакции, отторжения струпа, появления грануляции, начала краевой эпителизации и окончания заживления. На 25 и 30 сутки эксперимента определяли число животных, имеющих полностью эпителизированные раны.

Результаты. При стандартизации липофильного экстракта бархатцев прямостоячих сорта «Гавайи» установлено количе-

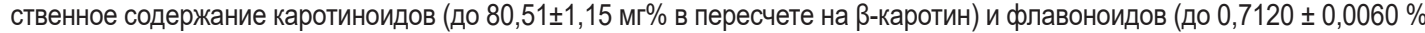
в пересчете на патулетин). Длительность заживления экспериментальных ран при применении исследуемого экстракта и референс-препарата составила до 30,7 $\pm 1,4$ суток и до 28,0 \pm 1,8 суток соответственно, что существенно меньше, чем в контрольной группе (до 47,7 $\pm 4,0$ суток). Полная эпителизация ран наблюдалась на 25 сутки эксперимента у $60 \%$ животных, получавших исследуемый экстракт, 70 \% животных, получавших референс-препарат и только у $10 \%$ животных, не получавших лечения. На 30 сутки эксперимента этот показатель составил 80, 90 и 30 \% соответственно. Результаты эксперимента достоверно свидетельствуют, что у животных, которых лечили изучаемым липофильным экстрактом, время заживления ожоговых ран было значительно меньше, чем у нелеченных животных контрольной группы, и практически не отличается от времени заживления у животных, которых лечили с использованием облепихового масла.

Выводы. Изучена ранозаживляющая активность липофильного экстракта, полученного из соцветий Tagetes erecta plena L. var. «Hawaii». Установлено, что длительность этапов и время полного заживления экспериментальной раны у животных, получавших исследуемый экстракт и референс-препарат, существенно ниже, чем у животных контрольной группы, не получавших лечение.

Nowadays, one of the most important problems of clinical care is assisting the healing process in acute and chronic wounds of various origins. In healthy people, minor injuries heal quite well. Significant injuries and physiological characteristics of the patient (age, general health, the presence of chronic diseases) have the adverse effect on the healing process [1]. Despite the fact that a significant number of drugs having a wide spectrum of pharmacological activity and influence on the various links of the wound process have been developed, there is a need for effective wound-healing medicaments $[1,2]$.

One of the modern directions of drug therapy in the treatment of wound injuries is the use of phytopreparations. External use of medicinal products containing plant components are characterized by soft action, low toxicity, high efficiency, as well as wide range of action due to a complex content of biologically active substances [2].

African marigolds (Tagetes erecta L.) are one of the most promising species of the genus Tagetes $L$. of the family Asteraceae. This kind is distributed worldwide. Marigold contains a variety of biological substances such as carotenoids, flavonoids, essential oil, hydroxycinnamic acids, amino acids, terpenoids, steroids, vitamins and minerals. In folk medicine, marigold is known as an anesthetic, antiseptic, diuretic, antiparasitic remedy. Extracts and drugs from individual compounds of Tagetes erecta L. show antimicrobial, wound healing, antioxidant, anti-inflammatory and analgesic activity $[3,4]$. In previous studies, we have found that the lipophilic extract of Tagetes erecta $\mathrm{L}$. belongs to the virtually non-toxic compounds (according to the compounds toxicity classification toxicity class $\mathrm{VI}$ ) and does not show local irritating and allergic effects [5].

\section{Aim of research}

The aim of our research was to study the wound healing activity of the lipophilic extract obtained from the inflorescences of African marigold tall forms of the variety "Hawaii" (Tagetes erecta plena L. var. "Hawaii").

\section{Materials and methods}

Lipophilic extract was obtained from the air-dried inflorescences of Tagetes erecta plena L. var. "Hawaii' collected during the active flowering period in the Zaporizhzhia region.

Lipophilic extract was obtained from 200.0 air-dried raw materials of inflorescences Tagetes erecta $\mathrm{L}$. which were crushed to the size of $13 \mathrm{~mm}$. The accurate weight of raw material sample was placed in a glass container and the corn deodorized oil in a ratio of 1:6 was added. This mix was steeped for 3 days and then extracted in a water bath at the temperature of $+60{ }^{\circ} \mathrm{C}$ for 1 hour. The extract was left to cool for 1 day. Extraction was repeated twice under similar conditions. The resulting extract was filtered, the raw material was squeezed. The extract was kept in a cool place at the temperature of $+5^{\circ} \mathrm{C}$ for 7 days. The settled residue which turned out in the process was separated. The 
resulting lipophilic extract was standardized to the content of carotenoids and flavonoids.

All the chemicals and solvents used in this study were of standard and analytical grade and solutions were freshly prepared prior to experimentation. Quantitative measurements of biologically active substances content were performed using a Specord-200 UV/Vis spectrophotometer (Analytic Jena).

Standardized lipophilic extracts from inflorescences Tagetes erecta plena L. var. "Hawaii" have been studied for wound healing activity in the Department of Experimental Pharmacology and Functional Biochemistry of the Medical Laboratory Center in Zaporizhzhia State Medical University.

The wound healing activity of the lipophilic extract has been tested on mature non-linear white rats weighing 180-200 $\mathrm{g}$ which were obtained from the Institute of Pharmacology and Toxicology of the Academy of Medical Sciences of Ukraine. The animals were kept in quarantine for 14 days before the experiment. Daily assessment of the behavior and general condition of the animals was carried out during the whole period of the quarantine. Morbidity and overall mortality of the animals were evaluated twice a day. Animals meeting the inclusion criteria for the experiment were randomized into 4 groups of 10 individuals each. The acceptability of randomization criterion was the external symptoms of disease absence and homogeneity of the groups by body weight $( \pm 20 \%)$. Animals which did not meet the criteria were excluded from the experiment. Animals were kept under the following conditions: 12 hours in the light, 12 hours in the dark with the air temperature $19-25^{\circ} \mathrm{C}$ and relative humidity of $50-70 \%[6,7]$.

The wound healing effect of the extract was determined on the example of a simulated burn healing. An electrothermal burn was applied on the skin liberated from the wool of $20 \times 60 \mathrm{~mm}$ in size (about $3 \%$ of the body surface) with the help of a special device. The samples of the extract and the reference preparation were applied to the burn area with a pipette dosing pump immediately after the injury and then until the wound was completely healed 2-3 times a day. As a reference preparation, sea buckthorn oil was used. The wound healing activity was visually assessed by the time of the perifocal reaction disappearance, skin sloughing, formation of granulation, initiation of marginal epithelialization and the end of healing. The number of animals with completely epithelialized wounds ("percentage of completely epithelialized wounds") was determined on days 25 and 30 of the experiment [8].

Statistical processing of the studied data was carried out by methods of mathematical statistics using sets of application programs Statistica for Windows 13 (StatSoft Inc., N JPZ804I382130ARCN10-J) and Microsoft Office Excel 10. Reliability of the data obtained was assessed by the Student t-criterion and the Mann-Whitney U-test. Results were considered statistically significant if differences were more than $95 \%(P<0.05)$.

\section{Results}

The received extract constitutes a dense orange oily liquid with the density about $0.8546 \pm 0.0309 \mathrm{~g} / \mathrm{ml}$, with characteristic taste and smell. The yield of the lipophilic extract was about $38 \%$.
Table 1. The healing time of burn wounds in animals of experimental groups (days), $(\bar{x} \pm \Delta \bar{x}),(n=10)$

\begin{tabular}{|c|c|c|c|c|c|}
\hline $\begin{array}{l}\text { Experimental } \\
\text { group }\end{array}$ & $\begin{array}{l}\text { the time } \\
\text { of perifocal } \\
\text { reaction } \\
\text { disappearance }\end{array}$ & $\begin{array}{l}\text { the time } \\
\text { of skin } \\
\text { sloughing }\end{array}$ & $\begin{array}{l}\text { the time } \\
\text { of granulation } \\
\text { formation }\end{array}$ & $\begin{array}{l}\text { the initiation } \\
\text { of marginal } \\
\text { epithelialization }\end{array}$ & $\begin{array}{l}\text { the end } \\
\text { of healing }\end{array}$ \\
\hline $\begin{array}{l}\text { № } 1 \\
\text { (control group) }\end{array}$ & $5.7 \pm 2.0^{*}$ & $13.1 \pm 1.7^{*}$ & $18.4 \pm 2.2^{*}$ & $19.0 \pm 2.0^{*}$ & $47.7 \pm 4.0^{*}$ \\
\hline $\begin{array}{l}\text { № } 2 \\
\text { (animals receiving } \\
\text { lipophilic extract) }\end{array}$ & $2.7 \pm 0.3^{*}$ & $6.7 \pm 1.0^{*}$ & $10.2 \pm 1.7^{*}$ & $14.1 \pm 1.1^{*}$ & $30.7 \pm 1.4^{*}$ \\
\hline $\begin{array}{l}\text { № } 3 \\
\text { (animals receiving } \\
\text { sea-buckthorn oil) }\end{array}$ & $2.0 \pm 0.3^{*}$ & $6.1 \pm 1.1^{*}$ & $8.2 \pm 1.1^{*}$ & $11.0 \pm 1.1^{*}$ & $28.0 \pm 1.8^{*}$ \\
\hline $\begin{array}{l}\text { № } 4 \\
\text { (intact animals) }\end{array}$ & - & - & - & - & - \\
\hline
\end{tabular}

Table 2. The percentage of completely epithelialized burn wounds on days 25 and 30 of the experiment $(P=95 \%)$

\begin{tabular}{l|l|l} 
Experimental groups & The 25th day & The 30th day \\
\hline № 1 (control group) & $10 \%$ & $30 \%$ \\
№ 2 (animals receiving lipophilic extract) & $60 \%$ & $80 \%$ \\
\hline № 3 (animals receiving sea-buckthorn oil) & $70 \%$ & $90 \%$ \\
\hline № 4 (intact animals) & - & - \\
\hline
\end{tabular}

The quantitative content of carotenoids (up to $80.51 \pm 1.15 \mathrm{mg} \%$ equivalent to $\beta$-carotene) and flavonoids (up to $0.7120 \pm 0.0060 \%$ equivalent to patuletin) was determined at standardization of the lipophilic extract of Tagetes erecta plena L. var. "Hawaii". Carotenoids and flavonoids which were contained in plants showed wound healing and anti-inflammatory activity stimulating the processes of tissue repair $[9,10]$.

The duration of healing stages of simulated burn in animals of experimental groups is shown in Table 1.

To assess the effectiveness of wound healing on days 25 and 30 of the study, the condition of burn wounds in experimental animals was evaluated. The obtained data are shown in Table 2.

\section{Discussion}

The most well-known activities of extracts obtained from plants of the genus Tagetes L. are anti-inflammatory, antioxidant and wound-healing $[3,11]$. This fact influenced the direction of our study to estimate the plant extract activity.

The result of a multi-stage wound healing process is restoration of the extracellular matrix and functional load of the skin, so the main direction of therapy for skin wounds is the creation of optimal conditions for complete tissue regeneration. In the preclinical study of the wound healing effect, models of an aseptic and infected wound are used. The process of wound healing includes the stages of exudation, proliferation and epithelialization. These phases are characterized by various changes, therefore, the proper therapeutic tactics development is important to create conditions for the optimal course of repair processes [12,13].

According to the findings from Table 1, the duration of healing stages in the groups of animals in which burn wounds were treated with the lipophilic extract and reference 
preparation was lower than in the control group animals. The greatest differences in the healing time between the studied extract and reference preparation were observed at the stage of marginal epithelialization initiation $(14.1 \pm 1.1$ days and $11.0 \pm 1.1$ days, respectively), the smallest differences - at the stages of perifocal reaction disappearance $(2.7 \pm 0.3$ and $2.0 \pm 0.3)$ and skin sloughing $(6.7 \pm 1.0$ and $6.1 \pm 1.1)$. The duration of complete healing of experimental burn wounds in groups of animals which were treated with the reference preparation and the extract tested was not significantly different.

Complete epithelization of wounds was observed on day 25 of the experiment in $60 \%$ of the animals receiving the extract, in $70 \%$ of the animals receiving the reference preparation and only in $10 \%$ of the animals which did not receive a treatment. As can be seen from the data presented in Table 2, on day 30 of the experiment, burn wounds were epithelialized only in $30 \%$ of the animals in the control group, while in the groups receiving the extract and sea buckthorn oil, the burn wounds were epithelialized in $80 \%$ and $90 \%$ of the animals, respectively.

The results of the experiment reliably testify to the fact that in animals treated with the studied lipophilic extract, the healing time of burn wounds was significantly higher than in the untreated control group animals and practically did not differ from the healing time in animals treated with sea buckthorn oil.

The studied lipophilic extract contains high concentrations of biologically active carotenoids and flavonoids. The high wound healing activity of the lipophilic extract from the inflorescences of Tagetes erecta plena L. var. "Hawaii" was correlated with a content of carotenoids and flavonoids.

According to the literature, biologically active flavonoids show anti-inflammatory and antimicrobial activity [10]. Carotenoids are characterized by wound healing activity due to activation of cell differentiation resulting in acceleration of wound healing [14]. Combination of antimicrobial and wound healing activity of the carotenoids and flavonoids creates optimal conditions for wound healing at all stages.

\section{Conclusions}

1. Lipophilic extract based on Tagetes erecta plena $L$. var. "Hawaii" have been standardized for amount of carotenoids and flavonoids.

2. The lipophilic extract from inflorescences Tageta erecta plena L. var. "Hawaii" has been studied for the wound healing activity.

3. The stages duration and the time of experimental wounds complete healing in animals receiving the studied extract and reference preparation were significantly reduced in comparison to the control group animals.

The experimental data obtained in this study can serve as the basis for further study of the lipophilic extracts of Tagetes erecta L. for the purpose of reparative drugs development.

Conflicts of interest: authors have no conflict of interest to declare. Конфлікт інтересів: віАсутній.
Information about authors:

Maliuhina 0. O., PhD, Assistant of the Department

of Pharmacognosy, Pharmaceutical Chemistry and Medicinal Preparations Technology, Zaporizhzhia State Medical University, Ukraine.

Smoilovska H. P., PhD, Associate Professor of the Department of Pharmacognosy, Pharmaceutical Chemistry and Medicinal Preparations Technology, Zaporizhzhia State Medical University, Ukraine.

Bielenichev I. F., Dr. hab., Professor, Head of the Department of Pharmacology and Medicinal Preparations, Zaporizhzhia State Medical University, Ukraine.

Mazulin O. V., Dr. hab., Professor, Head of the Department of Pharmacognosy, Pharmaceutical Chemistry and Medicinal Preparations Technology, Zaporizhzhia State Medical University, Ukraine.

Khortetska T. V., PhD, Senior Lecturer of the Department of Pharmacognosy, Pharmaceutical Chemistry and Medicinal Preparations Technology, Zaporizhzhia State Medical University, Ukraine.

\section{Відомості про авторів:}

Малюгіна О. О., канА. фарм. наук, асистент каф. фармакогнозії, фармацевтичної хімії і технології ліків, Запорізький державний медичний університет, Україна.

Смойловська Г. П., канА. фарм. наук, Аоцент каф. фармакогнозії, фармацевтичної хімії і технології ліків, Запорізький державний медичний університет, Україна.

Бєленічев І. Ф., А-р біол. наук, професор, зав. каф. фармакології та медичної рецептури, Запорізький Аержавний медичний університет, Україна.

Мазулін О. В., А-р фарм. наук, професор,

зав. каф. фармакогнозії, фармацевтичної хімії і технології ліків, Запорізький Аержавний медичний університет, Україна.

Хортецька Т. В., канА. фарм. наук, старший викладач каф. фармакогнозії, фармацевтичної хімії і технології ліків, Запорізький Аержавний медичний університет, Україна.

\section{Сведения об авторах:}

Малюгина Е. А., канА. фарм. наук, ассистент

каф. фармакогнозии, фармацевтической химии и технологии лекарств, Запорожский государственный медицинский университет, Украина.

Смойловская Г. П., канА. фарм. наук, Аоцент каф. фармакогнозии, фармацевтической химии и технологии мекарств, Запорожский государственный медицинский университет, Украина.

Беленичев И. Ф., А-р биол. наук, профессор, зав. каф. фармакологии и медицинской рецептуры, Запорожский государственный медицинский университет, Украина.

Мазулин А. В., А-р фарм. н., профессор,

зав. каф. фармакогнозии, фармацевтической химии и технологии лекарств, Запорожский государственный медицинский университет, Украина.

Хортецкая Т. В., канА. фарм. наук, старший преподаватель каф. фармакогнозии, фармацевтической химии и технологии мекарств, Запорожский государственный медицинский университет, Украина.

\section{References}

[1] Eming, S. A., Martin, P., \& Tomic-Canic, M. (2014). Wound repair and regeneration: Mechanisms, signaling, and translation. Science Translational Medicine, 6(265), 265sr6. Retrieved from http://doi.org/10.1126/ scitranslmed.3009337

[2] Trzhetsinsky, S. D., Mozul', V. I., Gernova, G. A., \& Fursa, N. S. (2014). Ranozazhivlyayushchaya aktivnost' mazi, soderzhashchej e'firnoe maslo travy tysyachelistnika pojmennogo [Wound healing activity of ointment containing essential oils of herb yarrow fl oodplain]. Current issues in pharmacy and medicine: science and practice, 2(15), 50-53. [in Russian]. doi: https://doi.org/10.14739/2409-2932.2014.2.26163

[3] Xu, L., Chen, J., Qi, H., \& Shi, Y. (2012). Phytochemicals and Their Biological Activities of Plants in Tagetes L. Chinese Herbal Medicine, 4(2), 103-117. doi: 10.3969/j.jssn.1674-6384.2012.02.004

[4] Singh, P., Krishna, A., Kumar, V., Krishna, S., Singh, K., Gupta, M., \& Singh,S. (2015). Chemistry and biology of industrial crop Tagetes species: a review. Journal of Essential Oil Research, 28(1), 1-14. do i: $10.1080 / 10412905.2015 .1076740$ 
[5] Malugina E. A., Mazulin A. V., Belenichev I. F., Smoylovskaya G. P. (2016). Vyvchennia hostroi toksychnosti lipofilnykh ekstraktiv karotynoidovmisnykh sortiv rodu chornobryvtsi (Tagetes L.) [Studying Acute Toxicity of the Lipophilic Extractions from Tagetes L. Containing Carotenoids]. Farmatsevtychnyi zhurnal, 1, 86-90. [in Ukrainian].

[6] (2009) Likarski zasoby. Nalezhna laboratorna praktyka: ST-N MOZU

42-6.0:2008. [Medicinal Products. Good laboratory practice ST-N MOZU 42-6.0:2008]. Kyiv: Ministerstvo okhorony zdorovia Ukrainy [in Ukrainian].

[7] Kozhemiakin, Yu. M., Khromov, O. S., Filonenko, M. A., \& Saifetdinova, G. A. (2002) Naukovo-praktychni rekomendatsii z utrymannia laboratornykh tvaryn ta roboty z nymy [Scientific and practical advice on the maintenance of laboratory animals and work with them]. Kyiv: Avitsenna. [in Ukrainian].

[8] Stefanov, A. V. (2002). Doklinicheskie issledovaniya lekarstvennykh sredstv [Preclinical studies of medicinal products]. Kyiv: Avicenna. [in Russian].

[9] Amorim-Carrilho, K., Cepeda, A., Fente, C., \& Regal, P. (2014). Review of methods for analysis of carotenoids. Trac Trends In Analytical Chemistry, 56, 49-73. doi: 10.1016/j.trac.2013.12.011.

[10] Raj Narayana, K., Sripal Reddy, M., Chaluvadi, M., \& Devarakonda, K. (2001). Bioflavonoids classification, pharmacological, biochemical effects and therapeutic potential. Indian Journal of Pharmacology, 33, 2-16.

[11] Oganesyan, E'. T., Andreeva, O. A., Terekhof, A. Yu., Podgornaya, Zh. V. (2004) Bioilogicheski aktivnye veshchestva lipofil'noj frakcii iz cvetkov Tagetes patula i izuchenie protivoozhogovoj aktivnosti na ikh osnove. Sovremennye naukoyomkie tekhnologii, 6, 107-108. [in Russian].

[12] Dobrejkin, E. A. (2013). E'ksperimental'noe obosnovanie sposoba modelirovaniya inficirovannoj ozhogovoj rany kozhi u laboratornykh zhivotnykh [Experimental substantiation of methods of modeling of infected burn wounds of skin in laboratory animals]. Saratovskij nauchno-medicinskij zhurnal, 9(2), 204-208. [in Russian].

[13] Kovaleva, M., Makarova, M., Kryshen, K., \& Alyakrinskaya, A. (2016). Obzor e'ksperimental'nykh modelej dlya izucheniya preparatov primenyaemykh pri kozhnykh zabolevaniyakh [Review of experimental models for the study of drugs used in skin diseases]. Mezhdunarodnyj vestnik veterinarii, 3, 160-167. [in Russian].

[14] Ribaya-Mercado, J. D., \& Blumberg, J. B. (2004). Lutein and Zeaxanthin and Their Potential Roles in Disease Prevention. Journal of the American College of Nutrition, 23, 522-527. 